\title{
Sami Indigenous Spirituality: Religion and Nation- building in Norwegian Sápmi
}

\author{
SIV ELLEN KRAFT \\ University of Tromsø
}

\begin{abstract}
In March 2008, the university library in Tromsø celebrated the opening of what they referred to as an 'indigenous room'. A collection of Sami literature was moved from its previous geographical and cultural context to what is today considered the more relevant company of American Indians, Australian aborigines and African peoples. ${ }^{1}$ Indicative of the increasing institutionalisation of the Sami as an indigenous people, the debate over what it means to be 'indigenous' is today important to Sami research, political strategies, cultural activities and religious creativity. In an attempt to take such innovations seriously, the article discusses some of the religious dimensions of Sami nation-building resulting from the ongoing processes of indigenisation. More specifically, I deal with a project structured by the international grammar of nation-building, which shares in the qualities of a civil religion and is at the same time shaped by 'indigenous spirituality'. Although a fairly recent construct, what I refer to as 'indigenous spirituality' is nevertheless a significant global discourse, developed primarily through the UN and international law. According to this perspective, indigenous peoples are the children of Mother Earth, and as such are opposed to and differentiated from the religions and worldviews of the 'western' world.
\end{abstract}

Keywords: Sami, nation-building, indigenous, nature spirituality, Mother Earth

Commonly referred to as the homeland of the Sami, Sápmi covers an area extending from northern Scandinavia to northwestern Russia, including parts of Norway, Sweden, Finland and Russia. Among the estimated 84000 self-defined Sami currently living in these areas, approximately 50000 live in Norway (Niezen 2004); it is this population, with an emphasis on the North Sami area, which constitutes the empirical basis for this article. The

1 The University of Tromsø presents itself as an indigenous university. It offers a Master's Program in Indigenous Studies, several classes on indigenous culture and a centre for Sami Studies. Scholars may also apply for funding from the Program for Sami research, in which the indigenous context is presented as important. 
Norwegian Sami share with most other indigenous peoples a history of forced cultural assimilation and a recent history of political mobilisation and cultural revival. A turning point in this context was the Sami resistance against a hydroelectric project during the 1980s: this was the start of a more extensive and systematic era of nation-building, along with an indigenous turn in Sami politics. The direct consequences included an amendment to the Norwegian Constitution, referring to the Sami (1988), and the setting up of a Sami Parliament (1989). Since then, the Sami have played a leading role in the international indigenous movement (Gaski 1993; Hansen 2008).

The religious implications of this indigenous turn have received only slight attention from scholars. In an attempt to contribute in this direction, I argued in a previous publication that the establishment of both Sami Christian theology and Sami Neo-shamanism must be understood in the context of indigenous discourse (see Kraft 2009). In the present article, the focus is shifted to the link between indigenous discourse and Sami nation-building. I first consider the development of indigenous thought and activism as an 'ism', insofar as it includes what international forums refer to as shared 'spiritual' characteristics. Second, my analysis of Sami nation-building is structured according to the concepts of past/origin, tradition/heritage and land/landscape. More specifically, I argue that the national past is located in the pre-Christian Sami religion, ${ }^{2}$ that ongoing folk religious traditions are presented as links to this past, that the Sami landscape is demarcated through the official mapping of holy places, and that these different processes are shaped by the above-mentioned 'ism'. Finally, I discuss whether the concept of 'civil religion' is useful as an analytical approach to this material. While to some extent adhering to the basic criteria of civil religion, the category of 'indigenous spirituality' has a global application, structured in contrast to 'the west', 'modernity' and the 'nation state'.

My primary sources consist of public documents connected to the official or semi-official level of Sami nation-building, including Sami Parliament debates, Norwegian public reports (NOU reports), information issued by officially sanctioned cultural institutions (museums, festivals etc.), and media coverage ${ }^{3}$ of relevant debates, occurrences and incidents. I have searched for the explicit deployment of religious components in connection with nation-

2 The pre-Christian Sami religion is not, of course, the only possible point of identification. From a secular nation-building perspective one could also include handicrafts, the art of telling stories, traditional costume etc.

3 'Media' in this case refers primarily to newspapers, and these are used primarily as sources (rather than as independent contributors to Sami nation-building). I have used the on-line news monitoring service Retriever (www.retriever.info.com) and have focused on newspapers published in northern Norway. 
alist concerns (here limited to the construction of a past, of traditions and landscapes), and I discuss such usage in relation to indigenous discourse. The range of sources is neither exhaustive nor intended to be representative of Sami nation-building. Rather, it is limited to public discourse, 'secular sources' and the contemporary political, cultural and intellectual elite in Sápmi. In addition, sources written in Sami have been excluded, ${ }^{4}$ and the emphasis has been placed on the northern Sami. The result is nevertheless a broad, varied and diverse corpus of sources. Inspired by the approach to meaning-making offered by critical discourse theory, I have tried to document and exemplify the broad dispersion and systematic features of 'indigenous spirituality' in Norwegian Sápmi. This endeavour includes a search for dominant representations, interpretative repertoires and the nodal points around which this discourse revolves and develops.

\section{Indigenous People, Rights Discourse and Religion}

Prior to the 1950s the term 'indigenous' was primarily used with reference to local or native people, or in the context of botanical plants (Niezen 2004, 70). Since then it has been employed in the construction of new global identities, including an estimated 300 million people from four thousand distinct societies (ibid, 4). Largely as a result of UN meetings and regulations, today 'indigenous people' is a legal concept that is connected to human rights; it is also, to some extent - and in certain circles - a cultural and religious category, based on the idea of shared traits across time and geography. Important among these characteristics is the idea of a close relationship with nature, with tradition and with the past. The term conveys an impression of 'traditional' peoples, with lasting connections to ways of life that that have survived 'from time immemorial' (ibid, 3; see also Brosius 1997, 53-5). As social anthropologist Ronald Niezen notes of his attendance at international meetings in Geneva on the rights of indigenous people:

\footnotetext{
4 I do not read any of the Sami languages and therefore do not have access to Ávvir (the only daily newspaper in Sami) and other sources in Sami. The Sami newspaper Sagat (in Norwegian) has been consulted in regard to the examples presented here, but a systematic comparison between Sami and Norwegian newspapers has not been conducted. Nor, one might add, is a clear-cut distinction between the two unproblematic. Apart from Sagat and Ávvir, both of which present themselves as Sami newspapers, most local newspapers in northern Norway are read by Sami and Norwegians alike and address, if to varying degrees, both groups of people. However, it is possible that the emphasis on indigenous spirituality is more pronounced in 'Norwegian' sources and in areas where Norwegians dominate, than in publications directed more exclusively towards a Sami audience.
} 
Many of the ideas that form the basis of indigenous peoples' claims have become part of a common parlance, and only when I had been to several meetings did I begin to think seriously about indigenous activism as an 'ism', as a social movement with a coherent network, a common world-view, and widely shared objectives. $(2004,66$.

To some extent a reversal of the primitivism of previous scholarship, indigenous people are now defined as a 'people of nature' in a positive sense. Characteristics that once placed them on a lower level of the evolutionary scale today account for their position as the noble caretakers of environmental wisdom. Previously represented by the majority culture, they now increasingly represent themselves, partly through the recently established forums of the UN. In doing so, social anthropologist Harald Prins has noted, indigenous peoples collaborate with outsiders in the production and reproduction of primitivist myths (Prins 2002, 56). Prins refers to this as 'the paradox of primitivism', implying that indigenous peoples not only recognize the primitivist formula, but that some of them also actively draw on it as a cross cultural 'structure of comprehension and imperatives for action' (ibid).

Contemporary Sami identity discourse exemplifies these tendencies. Several scholars have proposed that nature is a 'master myth' of Sami discourse (Gaski 2008, 227; Schanche 1993; Mathisen 2004; Hætta 2002). Ole Mathis Hætta, Sami scholar and former chairman of Norske samers riksforbund (The Norwegian Sami National Association), associates this concept with an environmental philosophy in which egalitarianism, peacefulness and an ahistorical view of the past are important elements, along with ecological care and an intimate relationship with nature (Hætta 2002, 59). As an example of the strong feelings connected to this myth, he notes that the Sami Parliament in 2001 unanimously banned a book about the Barents region due to a short passage claiming that the modern Sami reindeer business is damaging to nature. Other scholars (Sami and Norwegian) have themselves entered the world of mythical discourse. In the words of the Sami scholar Harald Gaski, the Sami constitute the 'modern natural man, still hearing and obeying the heartbeats of the Earth itself', and are-due to their high level of modernization - particularly suited to mediate between a western alienation from nature and an indigenous holistic thinking (Gaski 2004, 371).

What I referred to above as 'indigenous spirituality' further elaborates on the common denominators thus far presented. Not only close and intimate, indigenous peoples' relationship to nature is frequently granted a spiritual 
character. According to this perspective, indigenous people are the children of Mother Earth; they retain a spiritual relationship with nature, a continuity with a mythical past, and a holistic worldview - including environmental wisdom. Terms such as 'shamanism', 'animism' or simply 'spirituality' are commonly used to designate such qualities, and these terms - due partly to their elusiveness - frequently seem to be synonymous. This contributes further to the homogenization of indigenous people, such that distinct local characteristics merely constitute variations on a common theme. When viewed in this way, all indigenous people thus become collectively distinguishable from their 'western' surroundings. ${ }^{5}$

International laws have helped to standardize such notions by translating them into rights. In contrast to the 'freedom of beliefs' promoted by human rights, the beliefs of indigenous people tend to be explicitly connected to particular landscapes. To cite one example: ILO Convention 169, ratified by Norway in 1990, claims that governments must 'respect the special importance for the cultures and spiritual values of the peoples concerning their relationship with the lands or territories, or both as applicable, which they occupy or otherwise use, and in particular the collective aspects of this relationship' (Article 13,1). These values, moreover, are presented as being of broader importance to humankind as such. The convention calls attention to 'the distinctive contributions of indigenous and tribal peoples to the cultural diversity and social and ecological harmony of humankind and to international co-operation and understanding'. Publications connected to the UN repeat similar notions, thus indicating the pervasive acceptance and importance of these concepts for the international community. The socalled Cobo report is one example. Published by the UN in 1987, the Cobo report refers to the relationship between indigenous people and their land as 'deeply spiritual' and 'basic to their existence as such and to all their beliefs, customs, traditions and culture':

For such peoples, the land is not merely a possession and a means of production. The entire relationship between the spiritual life of indigenous peoples

5 The homogenizing tendencies implied in this perspective would seem to be contradicted by one of the main theoretical contributions from 'indigenous scholars', namely that scholars should focus on the local, on variation and on change. However, this is not necessarily so. Hardly anyone, Sami or Norwegian, scholar or layperson, would argue that all indigenous cultures are the same, identical or homogenous. But many people - including, I believe, at least some of the scholars drawing upon 'indigenous methodologies' - combine an emphasis on particularity and uniqueness with a basic division between indigenous people and western modernity. 
and Mother Earth, and their land, has a great many deep-seated implications. Their land is not a commodity which can be acquired, but a material element to be enjoyed freely. (Martinez Cobo, cited in Johansen 2003, 175.)

Spiritual aspects are also emphasized in Seeds of a New Partnership, published in connection with the International Year of the World's Indigenous People, in 1993; it includes excerpts from indigenous leaders from around the world as well as from Secretary-General Boutros Boutros-Ghali, Nobel Peace Prize winner Laureate Rigoberta Menchu, and Erica-Irene Daes, Chairperson of the United Nations Working Group on Indigenous Populations. 'Mother Earth' is referred to in most of these contributions, along with references to the holistic and ancient wisdom of indigenous peoples, particularly in regard to their environmentally sound relationship with nature. ${ }^{6}$

In the 'secular' sources for Norwegian Sápmi, explicit references to Mother Earth are rare. However, they are common in neo-shaman and Sami Christian circles, and are frequently implied in 'secular' sources. The work of Nils-Aslak Valkepää exemplifies the latter tendency, as do the ongoing revisions currently taking place in regard to this broader discourse. Valkepää is unrivalled in his position as national poet and musician of Sápmi, due partly to his contribution to the revitalization of yoik (a Sami form of singing) and partly to his poetry. His two latest works of poetry are titled Solen, min far ('The Sun, My Father', 1990) and Jorden, min mor ('The Earth, My Mother', 2006). The former, for which he received the Nordic Council's Literary Prize in 1991, is a selection of poetry about the Sami and draws upon traditional concepts. The notion of the Sami as sons and daughters of the sun has a solid background in pre-Christian Sami religion, and is referred to both in the Sami national anthem and in the Sami flag. The Earth, My Mother lacks a traditional anchoring, but closely resembles 'Mother Earth', with regard to both the language and the content of the book. The latter presents indigenous people from around the world through the main themes of indigenous discourse: responsibility for the earth, the oppressive nature of western civilisation, its subjugation of 'primitive people', and the emerging realisation that the world needs their wisdom.

Several studies have questioned the idea of Mother Earth as a universal concept and the related notions of indigenous people as her traditional

\footnotetext{
6 Similar references to a spiritual relationship with nature are repeated in the United Nations' Declaration on the Rights of Indigenous Peoples, adopted by the UN General Assembly in September 2007. In addition, declarations of the indigenous people's organizations frequently refer explicitly to Mother Earth as a common denominator of indigenous people's relationship to the land (see Appendix 1, in Posey 1999, p. 555-601). On Mother Nature imagery more generally, see Roach, 2005, and for critical accounts: Heath and Potter, 2004 and Gill, 1987.
} 
protectors (Petterson 1967; Gill 1987; Rønnow 2003). Scholars have also discussed problematic implications of these essentialist presuppositions and ongoing stereotypes. In the words of social anthropologist Arne Kalland, indigenous people have rights because they are people, not because they are saints (Kalland 2003), and not - one might add - because their ancestors somehow foresaw the environmental crisis and took steps to solve it. The rather limited effect of such perspectives perhaps indicates the limited potential of social science in so far as these naturalized concepts and notions were created through centuries of missions, expeditions, and research. On the other hand, this field of scholarship includes explicit and systematic contributions to the above-presented processes of naturalization, internationally as well as in Norway and Sápmi. In the words of historian of religion Cato Christensen, two distinct tendencies characterize contemporary Sami research: 'First, research which naturalises, supports and contributes to the construction of mythological concepts, and second, research based on a descriptive and/or critical approach to "Sami's nearness to nature", as part of a mythological or narrative complex' $(2007,7)$.

The first of these is marginal in the context of academia, but has a higher profile outside it through the media and through public and governmental committees. Today the most influential representative of such myth-making projects is Jens Ivar Nergård, Professor of pedagogics at the University of Tromsø. Nergård, a popular teacher and supervisor, is the author of several articles and books on Sami culture and religiosity. He is frequently cited in northern Norwegian media; his perspectives have been adopted both in Christian theological circles and by neo-shamans (see Kraft 2009), and he has been involved in important governmental committees and actions, including committees for the development of psychiatric treatment among the Sami and programs for the training of Sami teachers (ibid). Nergård's representation of what he refers to as 'Sami nature religion', moreover, has received little opposition from Sami scholars, partly - one may assume - because Sami scholars, including those connected with the Sami University College in Kautokeino and the Sami Centre at the University of Tromsø, have to a large extent ignored religion. Nergård's notion of Sami nature religion is characterized by two features. First, this religion has changed little since the pre-Christian era which preceded the Christian mission of the 17th century. Rather, 'the old nature religion entered a kind of inner exile, disguised under Læstadian Christianity' (a Lutheran revival movement which spread among the Sami during the late 19th century) (Nergård 2006, 108, my translation). From this exile it has served and still serves as a repository of wisdom and 
a buffer against forced assimilation. Second, the timeless essence of Sami religiosity revolves around the crucial importance of nature. A version of what Michael Shermer has termed 'the myth of the beautiful people', the Sami are generally represented as harmonious, peaceful and environmentally non-destructive. ${ }^{7}$

\section{Sami Nation-building - Past, Tradition, and Landscape}

Ronald Niezen notes as remarkable both the swift establishment of indigenous people as a global collective, and the similarity of this movement to the nationalist upheavals of the past two centuries $(2003,3)$. Much like the nationalist concern with 'natural ties, permanent homelands, archaic cultures, and timeless bonds of common history', indigenous-ness is connected to the landscape, to traditions and to the past (ibid). Unlike nation states, however, indigenous cultures often lack a state territory, and where nation states typically define themselves in terms of their own uniqueness, indigenous cultures increasingly situate their uniqueness within the framework of indigenous-ness as a global phenomenon.

\section{Past and History - the Pre-Christian Sami Religion}

Precisely when the Sami were introduced to Christianity is unclear, but we know from grave excavations that by the thirteenth century the cross was associated with Sami burial practices. A systematic mission was established by the seventeenth century, a period that also saw the extensive confiscation and destruction of Sami drums (connected with the noaidi) and sacred places. Most scholars consider that Christianity was established as the main religion from this period onward (Rydving 2004, 99). During the mid-nineteenthcentury the Læstadian revival gained hold in Sami communities, and since then Læstadianism has dominated in many Sami areas.

Nationalist history has to do with roots and origins, with a mythical space where 'we' were once defined and where later we can search for ourselves. In the words of Anne Eriksen: nationalist history has been concerned not merely to document that a given nation is old, but to an equal degree that throughout its extensive history it has preserved a cultural distinctiveness; that 'we' are still the same (Eriksen 1999, 71). Due to this logic, perhaps,

7 For a more detailed review of Nergård's perspectives, see Kraft 2007. On neo-romantic perspectives in research on Læstadianism, see also Drivenes and Niemi 2000. For a discussion of neo-primitivism in indigenous research, see Geertz 2004. 
Christianity (as a 'foreign' religion) has to a large extent been excluded from the Sami national project, while the pre-Christian Sami religion has emerged as a primary source. The symbols chosen, however, tend to be vague, implicit or ambiguous. A consistent theme in the following analysis, this tendency is probably related to the influential contexts of the Læstadian movement on the one hand and of Sami neo-shamanism on the other. An overemphasis on the centrality of the noaidi ritual in the formulation of Sami identity would upset the Læstadians (for whom the noaidi is a more or less demonic figure), and at the same time suggest a connection between Sami nation-building and neo-shamanic movements. Views on the latter appear to be changing, but many Sami see contemporary neo-shamanism as fabricated and inauthentic. As the folklorist Thomas DuBois comments, in an article on The Pathfinder (1987) by the Sami film-maker Nils Gaup:

Noaidevuohta (shamanism), the divinatory drum, and other aspects of Sami pre-Christian religion carry little charm or allure for many members of Gaup's insider community. While Scandinavians further to the south may dabble in neopaganist explorations of shamanic rituals and worldview with seeming impunity, many Sami in the late 1980s remained ambivalent or opposed to this aspect of their culture's past. The old religion continues to be viewed as illicit among many Nordic Sami Christians, who belong to either the Lutheran church or the Læstadian sect within it and who often view pre-Christian traditions as irreligious and idolatrous. (DuBois 2000, 268.)

Noaidevuohta is probably less controversial today than it was during the late 1980s. However, it is still a source of ambivalence and conflict; perhaps for this reason references tend to be vague and limited to concepts which in a late modern climate are generally acceptable. 'Nature religiosity' has appeared as one such concept. Pre-Christian Sami religion is commonly referred to as a nature religion, and some kind of nature spirituality is commonly ascribed to the Sami people in media discourse, in (neoromantic) academic research, and by the Sami intellectual and political elite. The Sami Parliament programme for 2002-2005 claims that 'the Sami culture is closely related to nature, both spiritually and in a practical sense', and that therefore 'nature is considered valuable, not only as the foundation for economic life, but to an equal extent in connection to Sami faith and values, knowledge, skills and personal living' (Gaski 2008, 224). The Norwegian official report (NOU 2000) on Sami teacher training similarly describes a 'deep understanding of nature as an ecological system' as central to traditional Sami knowledge; 
this knowledge, as the carrier of a distinct and non-western cosmology, is 'reflected in the relationship to nature, spirituality and religiosity' (NOU 2000, chapter 10-1).

The factual character of these statements, along with the lack of explanatory remarks, indicates that the claim is taken for granted; or, alternatively, that no one is expected to oppose it. Much like the 'God' of U.S. civil religion, 'nature spirituality' is wrapped in positive connotations, and is in addition so indistinct that it conflicts neither with Christian orientations nor with secular ones. Nature spirituality at the same time resonates with the notion of pan-indigenous spirituality, while allowing for boundary-maintenance vis-à-vis Norway, Norwegian-ness and even 'western-ness'. Nature is commonly described as integral to Norwegian-ness (Gullestad 1990), but not in connection to 'spirituality', and with different links to 'practical'. The 'nature' of Norwegian-ness typically refers to farming, leisure and expeditions and thereby to cultivated nature (farming), to sports and pleasure (leisure), or to visits to foreign landscapes (expeditions). To be 'closely related to nature, both spiritually and in a practical sense' carries different references and connotations, including references to wild and uncultivated nature, and - in contrast to Norwegian-ness - to a more holistic and tradition-based concept.

The most prominent national symbols originating in pre-Christian Sami religion are the drum and the yoik, both of which were central to the noaidi ritual. The Sami national flag, according to the Internet pages of the Sami Parliament, is inspired by the drum. The drum is also shown on the official map of Sápmi, drawn by the Sami artist Hans Ragnar Mathisen, which today is available in the form of postcards (Conrad 2004). At the Sápmi Theme Park in Karasjok, information signs are shaped in the form of drums (Viken 2006). The theme park was established around the turn of the twenty-first century and is situated near the Sami Parliament buildings. This is to my knowledge the first instance of the drum being used explicitly as a national symbol in connection with tourism; it thus signals the lifting of (unspoken) restrictions in commercial settings, at least in circumstances controlled by the Sami. Indicative of similar tendencies, during the last couple of years Sami-run schools have offered courses in the making of drums. Drums made at these schools are now sold at New Age festivals organised yearly in northern Norway, and are used for ritual purposes during such festivals and in Sami neo-shamanic courses.

Considering their historical origin, it may come as a surprise that these appropriations have not resulted in public debate and protests. The potential 
for secular interpretations may provide one answer. Since it was used in the noaidi ritual, the drum was the primary object of missionary attacks during the seventeenth century, and for that reason it has also become a symbol of Sami resistance. Meanwhile, the motif on the flag is said to be inspired by the drum; it does not actually contain a picture of one, and yoik has been granted a new and nationally respectable place in tradition as folk music. A ban on yoik in the schools was lifted in the mid-1990s, and today it forms a major part of music education in schools in Sami areas. In Finnmark, the traditionally important Easter festival now includes a Sami grand prix in two classes - traditional yoik and Sami music; in addition, several nationally popular yoik groups have appeared. In terms of recognition as a national symbol, it is also indicative that since the beginning of the 1990s yoik has been granted a role in highly profiled events, such as the Lillehammer Olympic Games in 1994 and the wedding of Crown Prince Håkon Magnus in 2001. In addition to being high-profile events, watched - in the case of the Olympics - by hundreds of millions of people, these are also arenas for the exhibition of national symbols. Through the performance of Valkeapää, Norway was represented as a nation that takes its indigenous group seriously; Sápmi, at the same time, was represented as a separate culture whose traditions differ from those of the Norwegians.

Controversies connected with yoik and the drum have in recent years been limited to their presence either in high-profile events involving the 'representation of the Sami' or in Christian ceremonies. Three recent controversies exemplify such tendencies. To the surprise of many Norwegians, the use of yoik during the Lillehammer Olympics resulted in a heated debate in Sami areas. A preacher from Karasjok, to cite one of the more critical contributors, claimed that yoik is 'an unpleasant reminder of the past, a cultural parasite that was a product of drunken drivel and heathen idol worship' (Graff 2008). The Crown Prince's wedding in 2001 provides a similarly high-profile example, this time within the additional context of a Christian ceremony. Upon the request of the royal couple, the internationally famous Sami musician Mari Boine performed a yoik version of a Christian hymn during the ceremony in the royal chapel - again to intense protests from Læstadians. Perhaps the most controversial event, however, was initiated by a Free Church minister in Kautokeino, who decided to create a yoik chant in honour of Jesus. This innovation was unanimously denounced by the Kautokeino Church council as blasphemous (ibid).

Used in contexts such as festivals and theatrical performances, religious symbols from the past appear to be imbued with fewer restrictions, partly 
- one may assume - because their connection to 'real life' is less clearly defined. ${ }^{8}$ In a particularly interesting instance, the theatre group Beaivvás Sámi Teáhter and the so-called 'Magical Theatre' at the Sápmi Theme Park in Karasjok explore these limits by inviting their audiences into a mythical dimension whose ontological status is unclear. Both are inspired by what scholars have referred to as the development of 'indigenous theatre', a tradition that integrates ritual expressions and oral traditions into theatrical performance (see Arntzen 1994). The 'Magical Theatre' is referred to as stálubákti or 'the mountain of the spirits', and is described in the web pages as follows:

a magical theatre which gives you insight into the worldview of the Sami prior to the arrival of Christianity in Sápmi. A pre-performance tells about modern Sami society. After that, the noaidi invites you into the main theatre for a deeper understanding of the origins of life and the forces of nature. History unfolds on the canvas before you and further out in the room, giving you a sense of partaking in the course of history. Perhaps this history will help you understand your own place in nature and in the world around you. (www.sapmi.no/sapmipark.)

The past, thus, is a foreign country, but it is also a place one can visit and learn from. In contrast to the more typical museological notion of learning about history as valuable in itself, this presentation of Sami history speaks directly to the personal identity of visitors and offers religious messages relevant to the present moment: a deeper understanding of the origins of life, of the forces of nature, and of one's place in nature and the world. We are dealing simultaneously with history on canvas and with experiences that convey the feeling of partaking in history. Again, the ambiguity intrinsic to the theatrical performance may reduce the potential for provocation by employing a discourse whose inclusiveness depends upon its ambiguity.

The Riddu Riddu festival in Manndalen provides a similar example, but has repeatedly gone further towards collapsing the boundaries between theatre, 'real life', and ritual. Initiated by a group of local young people in 1991, Riddu Riddu, which is referred to by the organisers as an indigenous festival, annually brings together some 3500 participants from all over the

8 The same may be true of films. The historian of religion Cato Christensen, in his ongoing $\mathrm{PhD}$. study of Sami cultural and religious revitalization, looks at Sami films from this perspective. See Christensen 2007 and 2008. 
world. It is supported financially by the Sami Parliament, and is today a media darling and an important forum for the exhibition and exploration of Sami indigenous identity in Norwegian Sápmi. Although mainly a music festival, it also facilitates the exchange of knowledge across indigenous cultures. As part of this project, Riddu Riddu has regularly organised 'traditional rituals'. In 2003, the local media reported what they referred to as the shamanic sacrifice of a goat, performed by three Tuvan shamans. The incident was met with anger from local Christians, who feared that such performances could 'bring back shamanism' (Nordlys 22.05.03). The town council also discussed the possible revival of shamanism and for this reason considered withdrawing their economic support for the festival (ibid). However, the (ethnically Norwegian) bishop, Per Oscar Kjølaas, was supportive of the event. He argued that it is both understandable and positive that different aspects of Sami culture and history are now being brought to light. In addition, the fact that historical references to Sami shamanism are limited makes it 'natural to gather information from people with a religion which may have much in common with Sami pre-Christian belief' (Nordlys 22.05.03). Such statements are typical of the widespread understanding of 'Shamanism' as a religion. They also indicate the somewhat difficult position of state church representatives: on the one hand they are collectively responsible for the harsh treatment of Sami religiosity in the past, and are therefore concerned with demonstrating their present tolerance towards it, while on the other they are faced with a Læstadian community for whom a pre-Christian religion continues to be highly problematic.

At the 2007 Riddu Riddu festival, the play Matki proved particularly controversial. Organised as an outdoor experience in which actors and audience together travelled to the world of the shaman, the play started with the ritual purification of the participants, followed by a drum-guided journey in search of power animals. The audience and actors then had to solve a labyrinth task, accompanied all the while by a yoik-singing shaman and a dancer portraying the pre-Christian Sami goddess Sáráhkká. The performance caused a heated debate among Sami scholars and artists in the regional newspaper Nordlys over what had actually taken place. Was it creative art or religious ritual? And what, more generally, constituted a respectful implementation of the past? (Nordlys 19.07.07, 23.07.07, 24.07.07.)

The provocative potential of this play was rather clear. If theatre has ritual-like qualities (Bell 1997), then experimental theatre - like this one - takes a step further by presenting the performances themselves as ritual. In addition, the advertisements for Matki resembled those of neo-shamanistic 
courses. In its introduction to the performance, the Riddu Riddu program invited visitors on a 'personal journey':

the shaman lets part of you die and part of you wake up. The actor gives you a role, yourself. The healer helps you with your past and presence. [...] Along the way you will meet Stallo, oracles, angles, crystal elves, the Mystic and many others. You can rest on a reindeer skin, in a lavvu (Sami tent). Become purified. You can die and be born again. Move on in life. As a new-born infant with all the experiences that the journey gives you. [...] There is nothing new under the Sun. Wake up to the Old Time, revisited now. (Riddu Riddu program, my translation. July 27 2008.)

Adding to this, celebrity shamans were given leading roles as actors. The chief shaman was played by Mikkel Gaup, who is today the best-known Sami actor in Norway, and whose interest in Sami neo-shamanism and healing is well known. Regional newspapers also noted that the director of Matki had attended courses by Ailo Gaup, one of the first and best-known Sami neo-shamans in Norway, and that the same Ailo Gaup was among the leading actors. ${ }^{9}$ In other words, it was difficult to distinguish between play and reality, between actor and shaman. Mikkel Gaup played a role that in everyday terms he $i s$, with the result that the audience actually participated in a neo-shamanic spirit journey, regardless of what they may have thought or believed about it.

Whether the organisers were conscious of such ambiguities is unclear. It is nevertheless interesting that the 'official' projects that have gone furthest in the direction of indigenous ritual performances have been located among the coastal Sami, where the processes of norwegianization have been particularly strong. The process of Sami nation-building has to a large extent been dominated by the Sami inhabitants of inner Finnmark. They inhabit what is today defined as the core Sami area, where the Sami Parliament and

\footnotetext{
9 See http://www.nordlys.no/kultur/riddu2007/article2875753.ece (visited July 28 2009). Ailo Gaup's biography (Gaup 2005) speaks clearly of the mixed background of Sami neo-shamanism. Born in Finnmark, Gaup grew up in a foster family near Oslo. Towards the end of the 1980s he returned to Finnmark, in search of a Sami noaidi that could teach him the art of the traditional drum journey. Gaup had at this point studied Sami history, but had not found any practical information. Local Sami knowledge of Shamanism proved absent in Finnmark at that time. However, at the tourist hotel in Alta he met a refugee from Chile with competence in the field of Shamanism. He gathered further theoretical and practical experience during a lengthy stay at Michael Harner's neo-shamanic centre in California, before he returned to Oslo and established himself as Norway's first Sami neo-shaman.
} 
other main institutions are located, and where the majority of the population speaks Sami. In contrast, young people in Manndalen during the 1960s and 70s had limited knowledge of Sami traditions; in certain coastal areas norwegianization was so effective that it was only later in life that people became aware of the Sami background of their grandparents and in some cases their parents. (Hauan 2003, 188.) The more tenuous Sami identity of these areas appears to have had two opposite effects. On the one hand, Læstadians in the heavily norwegianized areas of the coastal Sami are more critical of performances that incorporate elements of the pre-Christian Sami religion than Læstadians in the north. On the other hand, Sami in coastal areas have regularly gone further than the more confident Sami of inner Finnmark in their representations of the foreign country of the past and in the integration of indigenous spirituality, thus increasing the potential for conflict.

\section{Tradition - Folk Religiosity and Concepts of Continuity with the Past}

Continuity with the past is important to nation-building projects. The national identity of a people must somehow be connected to its imagined original essence in the past. Such links may be particularly important to indigenous cultures, due to their history of suppression and forced assimilation by the dominant society (Ginsburg 1991, 94). In the Sami context, folk religious traditions offer one solution to this problem. Commonly considered widespread in both the secular and Læstadian circles of Sami areas, folk religious traditions have traditionally been opposed by the church and are widely considered to constitute distinct traditions despite a perceived lack of definite dates of origin.

The most developed folk religious tradition with regard to nation-building is probably Sami medicine. One important reason for this is undoubtedly the importance of healing traditions in indigenous discourse, along with an interest in such traditions among the general public. Official reports describe Sami folk medicine as holistic, natural and traditional. ${ }^{10}$ Sami medicine has also been showcased during Riddu Riddu festivals, and in 2007 it was one of the highlighted topics of the above-mentioned Alternative Festival in Tromsø. Indicative of a positive view of 'alternative religiosity' among part of the ethno-political movement, this festival was co-hosted by Tromsø

10 See for instance NOU 1998, om alternativ medisin (Norwegian Public Report 1998, on alternative medicine) and NIFAB (National Information Centre For Alternative Medicine) http://www. nifab.no/. 
Samiske Folkeforbund, one of the main Sami political organisations in Tromsø. Interestingly, in her opening address to the first International Consultation on the Health of Indigenous People in 1999, Gro Harlem Brundtland, former Norwegian Prime Minister and at the time Director General of the World Health Organization, spoke in terms very similar to those of the New Age festival in Tromsø:

Indigenous peoples teach us about the values that have permitted mankind to live on this planet for many thousands of years without desecrating it. They teach us about holistic approaches to health that seeks to strengthen the social networks of individuals and communities, while connecting them to the environment in which they live. And they teach us about the importance of a spiritual dimension to the healing process. (Cited in Niezen 2004, 69-70.)

In contrast to the positive connotations granted to Sami folk medicine, equally widespread traditions connected to wood nymphs (huldrer), to so-called 'unrest in houses'('haunting'; uro i hus); and 'the people of the underground' (de underjordiske) occupy a more ambiguous position in Sami nation-building. On the one hand, due to their wide diffusion these traditions contribute to the bridging process referred to above. On the other hand, such traditions can be found not only in Sápmi but among Northern Norwegians in general. In addition, they lack the dignity of 'proper' religions: Norwegian folk religiosity is commonly categorized as a system of superstitions and supernatural beliefs, something akin to the pre-religiosity of evolutionary theory. Northern Norwegian media representations frequently imply such notions, in three ways. First of all, they give extensive coverage to certain types of folk-religious issues; secondly, they typically describe such issues as being widespread across ethnic lines in the past, but as being limited nowadays to the Sami; and third, they foreground incidents where folk religiosity comes into conflict with a modern and/or public institution.

As perhaps the main example of the latter, the media have since the turn of the century given considerable attention to cases in which the Norwegian Court has considered adherence to Sami folk religious traditions as justification for some kind of violation of the law. In March 2008, the Inner Finnmark Court acquitted a reindeer owner of charges of violating an animal protection law in slaughtering reindeer without the use of anaesthetics (NRK Nordnytt 11.03.08; NRK Sami Radio 10.03.08; Finnmark Dagblad 10.03.08). In his defence, the reindeer owner claimed that he had performed 
a traditional Sami blessing which alleviated the animal's pain. A few years earlier, a decision by the local authorities to tear down a ramshackle barn was cancelled because of the owner's fear of retribution from 'de underjordiske $^{\prime 11}$ The head of the building authority in Tromsø explained that their primary concern had been to secure the barn, and that this had been done. They had then chosen to respect the owner's belief in the people of the underground as 'so real that he dares not tear down the barn'. In addition, he noted, we must sometimes 'realise that there is more between heaven and earth than between the covers of local council regulations. This is such a case.' (Tromsø 06.11.04.)

The newsworthiness of these cases has to do with the fact that the judicial system considers religious beliefs as justification for violation of the law, and perhaps also with ongoing ambiguities in regard to the Sami. Particularly symptomatic in this regard, Nordlys, which is today the largest regional newspaper in Northern Norway, has in all of these cases chosen an inventive combination of aggressive headlines and sympathetic editorials. The editorials celebrate the cultural pluralism of the region, and through their stated respect for 'Sami tradition' underscore the editor's position (and more generally that of ethnic Norwegians) as modern and tolerant (see Kraft 2006).

A ritual performed in Keutokeino in 2006 exemplifies the more unusual case of a folk religious ritual being performed in an official setting. Mai Britt Utsi, Dean of the Sami College in Kautokeino, initiated the ritual in order to safeguard the support of the 'de underjordiske' prior to the construction of a new science centre. In line with what the media referred to as Sami ritual tradition, Utsi and representatives of Norsk Statsbygg (the Norwegian Directorate of Public Construction and Property) spent the night outdoors on the building site. Utsi herself served as ritual specialist for a ritual that included consuming a traditional meal, burying leftover meat along with the bones, and searching for omens.

In interviews with the press Utsi underlined the importance of keeping traditions alive and the responsibility of the college in doing so (Altaposten 10.06.06; Nordlys 8.06.06). She did not, however, explain how - in theological terms - the ritual works. In fact, the act of following traditions appears to be more important than offending the people of the underground, in this instance. A matter of 'belonging without believing' (to rephrase Grace

11 Since then, the media has reported on similar experiences at a hairdresser's and several kindergartens, and the bishop of Nord-Hålogaland has developed a so-called Sami liturgy intended for restoring peace in haunted houses. 
Davie's [1994] famous phrase), the ritual was primarily presented as a way of respecting Sami traditions. Meanwhile, outside journalists focused on the participation of the Norsk Statsbygg (which in general they found odd) and on the ritual as part of an old Sami tradition. Interestingly, the ritual became progressively older as it moved from a local to a national media context, despite the fact that local media coverage was the only primary source. What journalists in Finnmark referred to as 'Sami traditions and customs', the national media spoke of as ancient rituals, 'from time immemorial'. (Dagbladet 08.06.06; TV2 08.06.06; Den kristne avisen 08.06.06.)

Neither Utsi nor any of the other participants in the Statsbygg ritual explained the ritual in terms of indigenous discourse, such as respect for Mother Earth. The Sami musician and legal scholar Ande Somby, on his professional website at the University of Tromsø, makes such connections explicit:

In West-European thought the earth is considered as an object meant to be subjugated and used in the most profitable way. That the earth may also be considered a subject is known from the cultures of a considerable number of nature people. A subject, a mother, cannot simply be subjugated and reduced to the goal of profitable exploitation. In traditional Sami culture, for instance, one applied to the 'underground people' for permission to build before raising a gamme or a barn; great problems may thus have been connected to a marking of ownership of the earth by living human beings. The earth has autonomy and thereby cannot be owned. I think it is necessary to discuss these issues in order to decide whether the state or the Sami should be in charge of managing land and water in Finnmark. (Ande Somby's homepage, my translation; visited 28 July 2008.)

The ritual practices associated with obtaining permission and blessing for the construction of a new building here appear as typical of indigenous discourse. Why, then, was it not made relevant in the Statsbygg instance, and why - more generally - has it not been included in the standard vocabulary of Sami indigenous spirituality? Most important perhaps, current traditions may be more resistant to abrupt changes in content and interpretation than those drawn from the distant past. If the past is a foreign country, then the reshaping of its content may be less problematic. In comparison, the present is familiar and personal; in these cases, it consists of rituals that have traditionally been explained by circular arguments - 'we do this because it is our tradition'. Asked for comments on the Statsbygg ritual, leading Sami politi- 
cians settled for answers along these lines, noting that 'this is our custom' and 'everything need not be explained'. (Nordlys June 8 2006.)

\section{National Homeland - Sacred Places, Monuments and Memorials}

The construction of a national landscape implies that certain types of nature and certain places become representative of the nation and the national soul (Eriksen 1999, 47). In addition, the production of a national landscape is a means of demarcating territory. The Sami lack the geographical boundaries of an independent state and do not claim sovereignty. What they do have, and what appears to provide an alternative mapping of Sami territory, are sacred places. There are today a large number of known and demarcated sacred places in Sápmi, in the form of sacrificial places, graves, mountains and sites of previous ritual practice. Many of these are protected according to the law of 'cultural memories' (Kulturminneloven), which for Sami areas includes 'all traces of human activity in our physical environment, including localities to which historical happenings, faith or tradition are connected' ${ }^{12}$

The marking of places as sacred Sami sites constitutes an appropriation of these places and thereby a demarcation and visualization of Sápmi. Although symbolic in the sense that it is a national territory, the demarcation of Sápmi also has practical consequences in terms of the control and use of space. In 2004, to name what is perhaps the most dramatic example of such consequences, plans for an Olympic arena at Tromsdalstinden (a mountain near Tromsø) were cancelled in the wake of evidence of its status as a holy mountain in the Sami tradition (see Kraft 2004).

Through this process of mapping, monuments and memorials emerge as sacred places, albeit in somewhat elusive ways. Much like national symbols derived from the pre-Christian past, these monuments may be inscribed in different ways and with various meanings. Common to them is that they are officially holy, protected by law, and testify to the importance of the site both with respect to the Sami past and for contemporary Sami. In addition, these places offer points of connection between past and present, and between history and individuals. In the words of folklorist Anne Eriksen, 'when history - time - is located in space it gains a dramatically new accessibility' (1999, 92, my translation). The past may thus be experienced as

12 The latter claim implies what the law refers to as 'immaterial evidence', i.e. private or collective memories; these include Sami cultural memories more than 100 years old, which are thus automatically protected. See Kulturminneloven (www.lovdata.no/all/nl-19780609-050.html). 
'a now because it is connected to a here, a here that at the same time is part of modern people's personal and direct experience' (ibid).

At the level of nation-building, these types of monument participate in qualities typical of both 'nature religion' and the 'nature people' that they represent. They are in addition clearly distinguishable from the typical monuments of Norwegian and western cultures. Norwegian monuments are usually human-made, connected to the great deeds of individual men (and a few women), including kings, war heroes, Christian leaders, famous poets etc, and thus from an indigenous perspective are indicative of the image of western civilisation: a culture of competitive men and a culture of war. Moreover, they usually convey information through their inscriptions or through nearby information signs. In contrast, most Sami sacred places are natural formations, untouched or minimally shaped by human activity and technology. Thus allowed to 'speak for themselves', they are more inclusive with regard to possible interpretations and experiences, while at the same time calling attention to the ahistorical nature of the Sami past and the Sami people. These places have been there 'all the time', independent of the processes of colonialisation and norwegianization, and apparently completely unaffected by them. As such, the continuity and changelessness of Sápmi and Sami identity are grounded in the concrete forms of their sacred monuments.

The national monuments of the Sami may be linked to the global network of indigenous sacred places and thereby to a discourse of conflict between representatives of Mother Earth and her western oppressors. During the highly profiled case of Tromsdalstinden, this broader context was articulated by at least one of the contributors to the debate. The above-mentioned Sami artist Hans Ragnar Mathisen (creator of the official Sami map) was involved in the case as one of the two authors of a Sami Parliament report on the status of the mountain. In a newspaper article, he contextualized the issue through a story of his journey to Uluru, the holy mountain of the now extinct Uluridja people of Australia. Unlike the other tourists present, Mathisen chose to walk around the mountain rather than climb it:

I knew that according to the people's tradition it was a desecration to climb Uluru. Therefore I spent my time visiting the various mythical places, strange formations, surprising fountains and caves with paintings. An experience that still lives with me. Unable to brag that 'I have been on top of Ayers Rock!' I could at least tell myself this: 'I met the Uluridja people'. (Nordlys January 10 2004; my translation.) 
Further developing these connections, Mathisen presents a geological foundation for indigenous fellowship that places Tromsdalstinden at the centre. His starting point is the Continental Shelf some 550 million years ago, followed by the formation of the Caledonian mountain range and the development of glaciers. Through this development we have 'in our midst - in the original Sami core area - a greeting from Greenland and from Turtle Island, the indigenous name of the North American continent' (Nordlys January 10 2004; my translation). The article ends with a further reference to the gravity of the case. Everything he has worked for, Mathisen said, 'will be for nothing if Tromsdalstind becomes a downhill skiing slope' (ibid).

Not only a symbol of Sami identity, Tromsdalstinden emerges in Mathisen's writing as its substance and foundation. The holiness of the mountain is established through a connection to other holy mountains and to indigenous people of past and present, near and far. Furthermore, it seems to present Tromsdalstinden as the parent stock of a global and trans-historical network - as an indigenous axis mundi, created through the interaction of prehistoric forces.

\section{Sami Nation-building, Civil Religion and Indigenous Spirituality}

The American historians Richard Perard and Robert Linder have suggested five functions typical of civil religions. First, people widely accept a shared sense of their nation's history. Second, the society is related to a realm of absolute meaning, and third, it is perceived as in some sense special. Fourth, civil religions provide a discourse that ties the nation together. Finally, a collection of beliefs, values, ceremonies and symbols contribute to an overarching sense of unity. (Pierard \& Linder 1988, 22-3.)

Sami nation-building, as I have described it in this article, exhibits all of these functions. In contrast to the civil religions usually considered by scholars, however, Sami nation-building is constructed in opposition to 'western' cultures and to the state to which it belongs, while at the same time establishing connections to an indigenous people through an inclusive, global discourse. True to these connections, its mission to the world is considered a shared one, undertaken by indigenous people in general. An example of what scholars have referred to as the priestly and conservative version of civil religion, indigenous spirituality 'is inclined to celebrate and affirm the belief that [it] has a divinely appointed role in the world, is more likely to uphold traditional moral values, and appeals to a generally uncritical acceptance of the correctness and goodness of [its] values and their influence 
in the world' (Parson 2002, 3). Originally written in the context of U.S. civil religion, this statement also summarizes the essential orientation of these more recent developments in Sami nation-building. The values referred to are moreover identical to the more or less sacred values of the world order upon which it is based. The category 'indigenous people' is the result of a culture of international rights, and is consequently imbued with some of its sacred values, including environmental wisdom and cultural pluralism.

Ronald Niezen notes of the international movement of indigenous peoples that it should not be imagined 'merely as a global collectivity of those who claim indigenous rights and identity for themselves and their people' $(2004,70)$; rather, it derives much of its energies from a sensitive public, that is from 'non-indigenous helpers motivated by their own visions of global social justice and environmental restoration' (ibid). A recent past of brutal colonialisation may to some extent explain the presence of a sensitive audience, as well as centuries of primitivist constructions which in recent times have been reversed, in the sense that qualities that once were considered 'primitive' (in a negative sense) today are celebrated and admired. In the words of Anne Eriksen and Torunn Selberg:

In a world in which the fear of modernization's negative consequences - such as pollution of nature and ecological disasters - makes itself felt, indigenous peoples' close relationship to nature is represented as an alternative. A romantic idea is created, implying that indigenous people possess knowledge which make it possible for all of us to live in greater harmony with nature. (Eriksen \& Selberg 2006, 106; my translation.)

Equally influential in this regard is the international rights culture. Social anthropologist Kirsten Hastrup has noted that human rights culture is a particular kind of culture, in the sense that it is 'declared rather than lived', and that judicial thought is therefore 'constructive of social realities rather than merely reflective of them' (Hastrup 2001). Peter Beyer makes a similar point with regard to what in contemporary society counts as 'religion'. To the extent that 'religion' is made manifest in legal decisions, it becomes 'official'; such decisions thus 'have a significant effect on how both theological (religious) and scholarly (scientific) observers understand religion, and thus on how contemporary society constitutes this social domain'. (Beyer 2006, 5.)

The extent to which 'indigenous spirituality' is relevant or even apparent obviously varies among and within indigenous peoples. However, as an 
established dimension of indigenous forums in the UN, it today belongs to the hegemonic discourse of the international elite, where important decisions are made and strategies are outlined. Representatives of the Norwegian Sami have played an important role in these forums, and have to an unusual - if not unrivalled - extent integrated their own discourse of 'indigenousness' into their nation-building endeavours. Such institutionalisation is visible in the research, festivals, museums, public documents and monuments referred to in this article. It is also visible on Internet sites such as Samenet (www.sapmi.net) and Sami newspapers, radio and television stations, all of which present indigenous news from all over the world (see Niezen 2004). It is visible in recent developments in Sami film and music (Christensen 2007; 2008), and it is, finally, visible in the increasing emphasis placed on 'spirituality' and religious symbols. Indigenous spirituality, as presented by the contemporary Sápmi political and intellectual elite, has to do with proximity to nature, with ecological wisdom, and with respect and adherence to the traditions of the past; it also has to do with visions of indigenous identity constructed in opposition to 'western' culture and institutionalized 'religions'. Unlike the common usage of 'spirituality', as pertaining to the individual rather than to groups and to the private rather than to the public sphere (Knott 2005, 219), this usage is ascribed collectively to indigenous people, and is in the Sami context expressed through secular institutions and public initiatives.

\section{Bibliography}

\section{Arntzen, Knut Ove}

1994 Profesjonelt teater i Nord-Norge. - Einar Arne Drivenes \& Marit Anne Hauan \& Helge A. Wold (eds), Nordnorsk kulturhistorie. Bind to. Det mangfoldige folket, 393-403. Oslo: Gyldendal.

\section{Bell, Catherine}

1997 Ritual. Perspectives and Dimensions. New York: Oxford University Press.

\section{Beyer, Peter}

2006 Religions in Global Society. London: Routledge.

\section{Christensen, Cato}

2008 Film og konstruksjonen av samisk spiritualitet: En analyse av Veiviseren. - Guneriussen, Willy (ed.), Approaching Citizenship, En- 
counters $\mathcal{E}$ Place Enactment, Working Papers. CEPIN Research School Faculty of Social Sciences. Tromsø: University of Tromsø.

2007 Samisk identitetsforvaltning og global urfolksspiritualitet. Prosjektbeskrivelse til den flerfaglige forskerskolen CEPIN. Trømso: Universitetet i Tromsø. [http://uit.no/cepin/7842/]

\section{Conrad, Joann}

2004 Mapping Space, Claiming Place. The (Ethno-) Politics of Everyday Geography in Northern Norway. - Anna-Leena Siikala \& Barbro Klein \& Stein R. Mathisen (eds), Creating Diversities. Folklore, Religion and the Politics of Heritage, 165-89. Helsinki: The Finnish Literature Society. (Studia Fennica Folkloristica 14.)

Davie, Grace

1994 Religion in Britain since 1945: Believing without Belonging. Oxford: Blackwell Publishing.

\section{Drivenes, Einar Arne \& Einar Niemi}

2000 Også av denne verden? Etnisitet, geografi og læstadianisme mellom tradisjon og modernitet. - Øyvind Norderval \& Sigmund Nesset (eds), Vekkelse og vitenskap: Lars Levi Læstadius 200 år, 156-86. Tromsø: Ravnetrykk.

DuBois, Thomas A.

2000 Folklore, Boundaries and Audience in The Pathfinder. - Juha Pentikäinen (ed.), Sami Folkloristics, 255-74. Turku: NIF.

\section{Eidheim, Harald}

1971 Aspects of the Lappish Minority Situation. Oslo: Universitetsforlaget.

\section{Eriksen, Anne}

1999 Historie, minne og myte. Oslo: Pax Forlag.

\section{Eriksen, Anne \& Selberg, Torunn}

2006 Tradisjon og fortelling. En innføring i folkloristikk. Oslo: Pax Forlag.

\section{Gaski, Harald}

2004 Indigenous Interdisciplinary Internationalism: the Modern Sami Experience with Emphasis on Literature. - Takashi Irimoto \& Takado Yamada (eds), Circumpolar Ethnicity and Identity, 371-87. Osaka: National museum of ethnology.

1993 The Sami People: The 'White Indians' of Scandinavia. - American Indian Culture and Research Journal 17 (1), 115-28.

\section{Gaski, Lina}

2008 Sami Identity as a Discursive Formation: Essentialism and Ambivalence. - Henry Minde (ed), Indigenous Peoples. Self-determination, Knowledge, Indigeneity, 219-36. Delft: Eburon Academic Publishers. 


\section{Gaup, Ailo}

2005 The Shamanic Zone. Oslo: Three Bear Company.

\section{Geertz, Armin}

2004 Can we Move beyond Primitivism? On Recovering the Indigenes of Indigenous Religions in the Academic Study of Religion. - Jacob K. Olupona (ed.), Beyond Primitivism. Indigenous Religious Traditions and Modernity, 37-70. New York: Routledge.

\section{Gill, Sam D.}

1987 Mother Earth: an American Story. Chicago: University of Chicago Press.

Ginsburg, Faye D.

1991 Indigenous Media: Faustian Contract or Global Village? - Cultural Anthropology 6, 92-112.

\section{Graff, Ola}

2007 Music, Sapmi - Becoming a Nation, [www.sapmi.uit.no], (visited by me on 28.07.08).

\section{Gullestad, Marianne}

1990 Naturen i norsk kultur. Foreløpige refleksjoner. - Trine Deichmann-Sørensen \& Ivar Frønes (eds), Kulturanalyse, 81-96. Oslo: Gyldendal.

\section{Hansen, Lene}

2008 Storm på kysten. Tromsø: MargBok.

\section{Hastrup, Kirsten}

2004 Kultur. Det fleksible fxllesskab. Århus: Aarhus Universitetsforlag.

2001 Legal Cultures and Human Rights. The Challenge of Diversity. Great Britain: Anthony Rowe Limited.

\section{Hauan, Marit Anne}

2003 Riddu Riddu - et sted å lære. - Marit Anne Hauan et al. (eds), Karlsøy og verden utenfor. Kulturhistoriske perspektiver på nordnorske steder,186-207. Tromsø: Museums skrifter XXX.

\section{Heath, Joseph \& Andrew Potter}

2004 Nation of Rebels. Why Counterculture became Consumer Culture. New York: HarperCollins Publishers.

\section{Hætta, Ole Mathis}

2002 Samene - Nordkalottens urfolk. Kristiansand: Høyskoleforlaget.

\section{Johansen, Ann-Gøril}

2003 Ett skritt fram og to tilbake. Om samerettsutvalgets forslag til regler om vern mot naturinngrep i samiske bruksområder. - Bjørn Bjerkli 
\& Per Selle (eds), Samer, makt og demokrati, 53-62. Oslo: Gyldendal Akademisk.

\section{Kraft, Siv Ellen}

2006 Åndenes land. Om Statsbygg, de underjordiske og spøkelser i NordNorge. - Din. Religionsvitenskapelig tidsskrift 2-3, 1-14.

2004 Et hellig fjell blir til om samer, OL og arktisk magi. - Nytt Norsk Tidsskrift 21 (3/4), 237-49.

\section{Mathisen, Stein R.}

2004 Hegemonic Representations of Sami Culture. From Narratives of Noble Savages to Discourses on Ecological Sami. - Anna-Leena Siikala \& Barbro Klein \& Stein R. Mathisen (eds), Creating Diversities. Folklore, Religion and the Politics of Heritage, 17-30. Helsinki: The Finnish Literature Society. (Studia Fennica Folkloristica 14.)

\section{Nergård, Jens Ivar}

1994 Det skjulte Nord-Norge. Oslo: Gyldendal.

2006 Den levende erfaring. En studie av samisk kunnskapstradisjon. Oslo: Cappelen Akademisk.

\section{Niezen, Ronald}

2004 A World Beyond Difference. Cultural Identity in the Age of Globalization. Malden: Blackwell publishing.

2003 The Origins of Indigenism: Human Rights and the Politics of Identity. Berkeley: University of California Press.

\section{Parson, Gerald}

2002 Perspectives on Civil Religion. Ashgate: Open University.

\section{Pettersson, Olof}

1967 Mother Earth: An Analysis of the Mother Earth Concept According to Albrecht Dieterich. Lund: Scripta Minora Regia Societatis Humaniorum Litterarum.

\section{Pierard, Richard V. \& Robert Dean Linder}

1988 Civil Religion and the American Presidency. Michigan: Zondervan.

\section{Posey, Darrell. (ed.)}

1999 Cultural and Spiritual Values of Biodiversity. Nairobi, Kenya: United Nations Environmental Programme.

Prins, Harald E. L.

2002 Visual Media and the Primitivist Perplex. Colonial Fantasies, Indigenous Imagination, and Advocacy in North America. - Faye D. Ginsburg et al. (eds) Media Worlds: Anthropology on New Terrain, 58-74. Ewing: California Press. 
Roach, C. M.

2005 Mother Nature Imagery. - Bron Tylor (ed.) Encyclopedia of Religion and Nature vol. 2, 1107-10. London: Thoemmes Continuum.

\section{Rydving, Håkan}

2004 Saami Responses to Christianity: Resistance and Change. - Jacob K. Olupona (ed.) Beyond Primitivism. Indigenous Religious Traditions and Modernity, 99-108. London: Routledge.

\section{Rønnow, Tarjei}

2003 Moder jord. Et moderne nøkkelsymbol. - Din. Tidsskrift for religion og kultur 2, 34-44.

\section{Schanche, Audhild}

1993 Kulturminner, identitet og etnisitet. - Dugnad 19 (4), 55-64.

\section{United Nations}

1994 Seeds of a New Partnership. Indigenous Peoples and the United Nations. New York: United Nations.

\section{Valkeapää, Nils-Aslak}

2006 Jorda, min mor. Kautokeino: MediaPrint Uddevalle (translated and introduced by Harald Gaski).

1990 Solen, min far. Kautokeino: DAT.

\section{Viken, Arvid}

2006 Tourism and Sàmi Identity - an Analysis of the Tourism-Identity Nexus in a Sàmi Community. - Scandinavian Journal of Hospitality and Tourism 6 (1), 6-24.

\section{Internet sources}

ILO C169 Indigenous and Tribal Peoples Convention, 1989. Convention concerning Indigenous and Tribal Peoples in Independent Countries. ILOLEX, Database of International Labour Standards, International Labour Organization <http://www.ilo.org/ilolex/cgi-lex/convde.pl?C169> accessed 20 May 2010.

Kulturminneloven [online database], Miljøverndepartementet <http://www. lovdata.no/all/nl-19780609-050.html> accessed 20 May 2009.

NOU 1997: 4, Naturgrunnlaget for samisk kultur. Utredning fra et utvalg oppnevnt ved Kronprinsregentens resolusjon 10. oktober 1980. Avgitt til Justis- og politidepartementet januar 1997. Norges offentlige utredninger. Justis- og politidepartementet, Oslo. 
<http://www.regjeringen.no/nb/dep/jd/dok/NOUer/1997/ NOU-19974.html?id=140720> accessed 20 May 2009.

NOU 1998: 21 Alternativ medisin. Utredning fra et utvalg oppnevnt av Sosial- og helsedepartementet april 1997. Avgitt til Sosial- og helsedepartementet 15. desember 1998. Norges offentlige utredninger. Helse- og omsorgsdepartementet, Oslo. <http://www.regjeringen. no/nb/dep/hod/dok/NOUer/1998/NOU-1998-21.html?id=141407> accessed 20 May 2009.

NOU 2000: 3 Samisk lærerutdanning - mellom ulike kunnskapstradisjoner. Utredning fra et utvalg oppnevnt av Kirke-, utdannings- og forskningsdepartementet av 8. mai 1998. Avgitt september 1999. Norges offentlige utredninger. Kunnskapsdepartementet, Oslo. <http://www.regjeringen.no/nb/dep/kd/dok/NOUer/2000/NOU-2000-3.html?id=142575> accessed 20 May 2009.

Riddu Riđäu, internasjonal urfolksfestival / riikkaidgaskasaš álgoálbmotfestivála [website] <http://www.riddu.no/> accessed 20 May 2009.

Sámediggi - Sametinget [website] <http://www.samediggi.no> accessed 20 May 2009.

Sapmi - nášuvdna riegada, en nasjon blir til, becoming a nation [website], Tromsø Museum <http://sapmi.uit.no> accessed 20 May 2009. 